\title{
Lucifer Yellow filling of area X-projecting neurons in the high vocal center of female canaries
}

\author{
Stacey Benton ${ }^{\text {a, }}$, Jessica A. Cardin ${ }^{\mathrm{b}}$, Timothy J. DeVoogd ${ }^{\mathrm{a}, \mathrm{c}}$ \\ ${ }^{\mathrm{a}}$ Neurobiology and Behavior, Mudd Hall, Cornell University, Ithaca, NY 14853-2702, USA \\ ${ }^{\mathrm{b}}$ Department of Neuroscience, 215 Stemmler Hall, University of Pennsylvania, Philadelphia, PA 19104, USA \\ ${ }^{c}$ Department of Psychology, Uris Hall, Cornell University, Ithaca, NY 14853, USA
}

Accepted 28 April 1998

\begin{abstract}
The avian high vocal center (HVC) is a complex forebrain nucleus that coordinates the sensorimotor integration necessary for song learning and production. It receives auditory and potentially somatosensory input, and sends major projections to vocal motor and anterior forebrain nuclei. The HVC has at least four morphological classes of neurons for which the connectivity remains uncertain. Previous studies have alluded to the functional identity of the cell classes, but none have provided the definitive evidence necessary for subsequent identification of behaviorally relevant changes within known neuronal populations. The cell filling technique we have adapted for use in the song system provides a method by which hodologically identified classes can be described with precision, and song related changes in their morphology can be readily identified. Neurons in female canaries (Serinus canarius) that project to Area X of the anterior forebrain pathway were retrogradely labeled, selectively filled with Lucifer Yellow in a fixed slice preparation, and converted to a Golgi-like stain through an immunocytochemical reaction. We have identified Area X-projecting neurons as belonging to the thick dendrite class of Nixdorf et al. [B.E. Nixdorf, S.S. Davis, T.J. DeVoogd, Morphology of golgi-impregnated neurons in hyperstriatum ventralis, pars caudalis in adult male and female canaries, J. Comp. Neurol. 284 (1989) 337-349] and have shown definitively that they are among the HVC neurons that can receive direct auditory input, as this cell class has short dendrites that extend into the shelf region ventral to HVC that is known to receive auditory inputs. Well-filled axons had collaterals that ramified and terminated within the nucleus, demonstrating a network through which Area X-projecting cells can contribute to intrinsic HVC communication. (C) 1998 Elsevier Science B.V. All rights reserved.
\end{abstract}

Keywords: Songbird; Cell morphology; Dendrite; Spine

\section{Introduction}

The avian song system consists of a discrete set of brain nuclei devoted to the learning and production of song. Descending from the high vocal center (HVC), the nuclei are organized into two pathways. HVC neurons that project to the robust nucleus of the archistriatum (RA) [21] contribute to the primary motor pathway for song production, while those that project to Area $\mathrm{X}$ in the parolfactory lobe $[5,21]$ contribute to the anterior forebrain pathway that is involved in song learning [3] and in maintaining song stereotypy [2]. HVC receives at least four afferent projec-

\footnotetext{
* Corresponding author. Fax: +1-607-255-8433; E-mail: sb12@cornell.edu
}

tions; auditory input from the L1 and L3 subdivisions of the field L complex and from nucleus interfacialis (NIf) in the neostriatum $[8,9,11,16,21,31]$, potentially multisensory input from the thalamic nucleus uvaeformis (Uva) $[23,30,32]$, and an unclassified input from the medial portion of the magnocellular nucleus of the anterior neostriatum (mMAN) [5,21] (Fig. 1). HVC neurons have complex auditory properties that are temporally synchronized across the nucleus $[13,14,27]$, and several studies indicate that HVC coordinates the motor commands for song syllables in zebra finches (Taenopygia guttata) [29,33]. Thus, HVC represents a nexus of sensorimotor integration in the song system. However, the specific mechanisms at work in HVC have proved difficult to decipher. No evidence has been found for topographic projections either onto or from HVC $[8,9,13,21,27]$, and the cytoarchitechtonically distinct subregions described by Fortune and Margoliash [9] have 


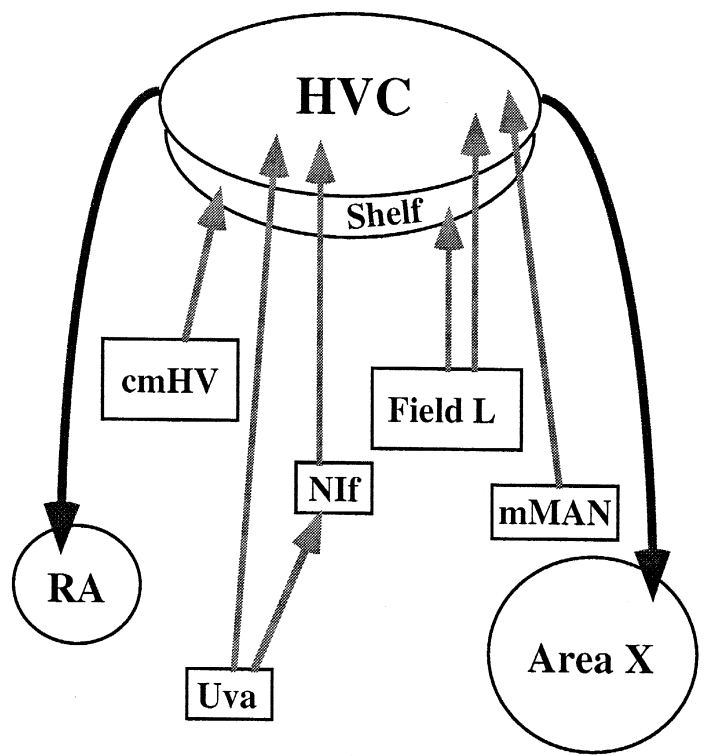

Fig. 1. Afferent and efferent connections of HVC. Both the afferent terminals and the efferent projection neurons are distributed throughout HVC. HVC, high vocal center; RA, robust nucleus of the archistriatum; cmHV, caudomedial hyperstriatum ventrale; Uva, nucleus uvaeformis; NIf, nucleus interfacialis; Shelf, region along ventrolateral HVC; Field L, thalamorecipient auditory forebrain; mMAN, medial portion of the magnocellular nucleus of the anterior neostriatum; Area X of the parolfactory lobe.

not been related to discrete functions. It is, therefore, not possible to extract the function or connectivity of an HVC neuron from its morphology or topographic location.

Understanding how HVC functions requires that its components be dissected and individually examined. Three types of spiny neurons, furry dendrite (FD), thick dendrite (TD) and short dendrite (SD), have been identified in canary (Serinus canarius) HVC by the statistical analysis of their morphological features in Golgi-stained material [18]. The connectivity of these classes is not known with certainty. Two studies, involving cells either filled with horseradish peroxidase (HRP) following intracellular recording [10] or filled retrogradely with fluorescent and biotinylated dextrans [9], have suggested that Area X-projecting cells are of the TD class. Conclusive confirmation of neuronal class was not possible, however, because the cells were few in number or not sufficiently filled. The intrinsic HVC connectivity has also remained elusive. Communication within the nucleus is extensive [9,28], but tracing techniques have not been fine enough to reveal the nature of the intrinsic communication network.

We report here a novel approach in song system research that employs an established cell filling technique to examine and quantify with precision individual projection neurons of known type in HVC. Specifically, retrogradely labeled Area X-projecting neurons are selectively impaled and filled with Lucifer Yellow (LY), which is then converted to a light stable product through an immunocytochemical reaction. The fine morphological features of these cells can then be quantified to accurately describe the hodologically identified cell class, and differences among treatment groups can readily be detected. This cell filling technique has been applied successfully in mammalian systems to demonstrate, for instance, neurotransmitterassociated changes in the morphology of identified cell types in the nucleus accumbens [17] and in the lateral geniculate nucleus [24]. The data presented here provide confirmation that Area X-projecting neurons belong to the TD class, as well as evidence for a network of recurrent collaterals in $\mathrm{HVC}$ arising from axons traveling to Area X.

\section{Methods}

\subsection{Subjects}

Adult female canaries were housed in a free-flight colony room and maintained on artificial daylight cycles to simulate either short day, non-breeding conditions $(8 \mathrm{~h}$ light for 1-3 months) or long day, breeding conditions (14 $\mathrm{h}$ light for 1-2 months) at the time of sacrifice. Long day females were divided into two groups differing in hormone treatment. Testosterone (T)-treated females received a silastic implant of $5 \mathrm{~mm}$ packed testosterone (Sigma) approximately four weeks prior to sacrifice. All T-treated females sang, had a male-like external cloacal morphology ('pointed'), and had regressed ovaries with undeveloped eggs, thus confirming the masculinizing effects of testosterone. Untreated long day females did not receive implants and behaved as normal breeding condition females; none sang, and all had enlarged ovaries with developing eggs. Animal housing, surgery and sacrifice were conducted under guidelines established by the Cornell University Center for Research Animal Resources.

\subsection{Retrograde tracing}

Birds were anesthetized with a mixture of 5\% xylazine (Rompun, $8.6 \mathrm{mg} / \mathrm{kg}$ body weight, Bayer), 95\% ketamine (Vetamine, $155.7 \mathrm{mg} / \mathrm{kg}$, Malinckrodt Veterinary) for the duration of the $90 \mathrm{~min}$ surgical procedure. A Hamilton syringe fitted with a glass tip was placed over Area X using stereotaxic coordinates derived from an atlas [26] and refined experimentally. The tip was broken back to a diameter of approximately $20 \mu \mathrm{m}$ and filled with a 1:1 mixture of FITC and RITC latex microspheres (LumaFluor). The combination of retrograde tracers served several purposes. Fluorescein microspheres (FITC) were visible with the same filter combination used for LY injection and, therefore, provided the target in Area X-projecting cells at which to direct the LY filled electrode. Rhodamine microspheres (RITC) were used primarily for photographic purposes. They were initially intended to 
provide an alternate means of confirming that the electrode was in a labeled cell, but switching to the rhodamine filter caused too much vibration in the preparation.

Retrograde tracer was pressure injected bilaterally into Area $\mathrm{X}$ in two or four penetrations for a total of $0.24 \mu \mathrm{l}$ per hemisphere over $25 \mathrm{~min}$. Two injections were sufficient to label cells in HVC, but four penetrations increased the probability of placing tracer into Area $\mathrm{X}$ without compromising the accuracy of retrograde tracing. The injection site was intended to be large and not confined to the body of Area X, as there are no identified projections from HVC to the region surrounding Area X [9]. All birds recovered from the surgeries and were returned to the colony room within one day.

\subsection{Tissue preparation}

Two weeks to six months after tracer injection, the birds were killed with an overdose of Chloropent (Fort Dodge Labs) and perfused transcardially with $0.1 \mathrm{M}$ phosphate buffer (PB; $12.2 \mathrm{~g}$ sodium phosphate dibasic anhydrous and $2.6 \mathrm{~g}$ sodium phosphate monobasic in 11 distilled water, $\mathrm{pH} 7.4$ ), followed by $4 \%$ paraformaldehyde (purified prill, EM Sciences) in PB. The brains were removed immediately, split into two hemispheres, and postfixed for $30 \mathrm{~min}$. The quality of the perfusion was critical for successful cell filling. Poorly or underfixed tissue was difficult to work with and rarely produced useful data. Cells did not retain the dye well, soft tissue would clog the electrode tip during filling, and filled cell bodies could tear away from the section when the electrode was withdrawn. Accordingly, the EM grade of paraformaldehyde was found to be superior to non-purified grades as it resulted in better perfusions, and a $30 \mathrm{~min}$ post-fixation time was ideal because shorter intervals did not provide sufficient fixation.

Brains were cut on a vibratome into $150 \mu \mathrm{m}$ thick sections in the sagittal plane. This thickness was optimal because the majority of dendrites filled completely and no subsequent resectioning was required for immunostaining. Brains were coated in a thin layer $(1-2 \mathrm{~mm})$ of $8 \%$ gelatin before sectioning to reduce curling of the tissue in subsequent reactions. Tissue sections were then stored in PB with $0.03 \%$ sodium azide as preservative until filling. The best results were obtained within the first two weeks, but quantifiable cells could be filled up to a month after sacrifice.

\subsection{Lucifer Yellow injection}

Sections containing HVC were mounted in a modified petri dish designed to fit securely on the stage of an Olympus $\mathrm{BH} 2$ fluorescent microscope. The petri dish was fixed to a plastic platform that attached to the stage with screws and could be removed easily for access to the tissue. A short silver wire was permanently inserted at the base of the dish for attachment to ground. The tissue section, except for a small area centered over HVC, was
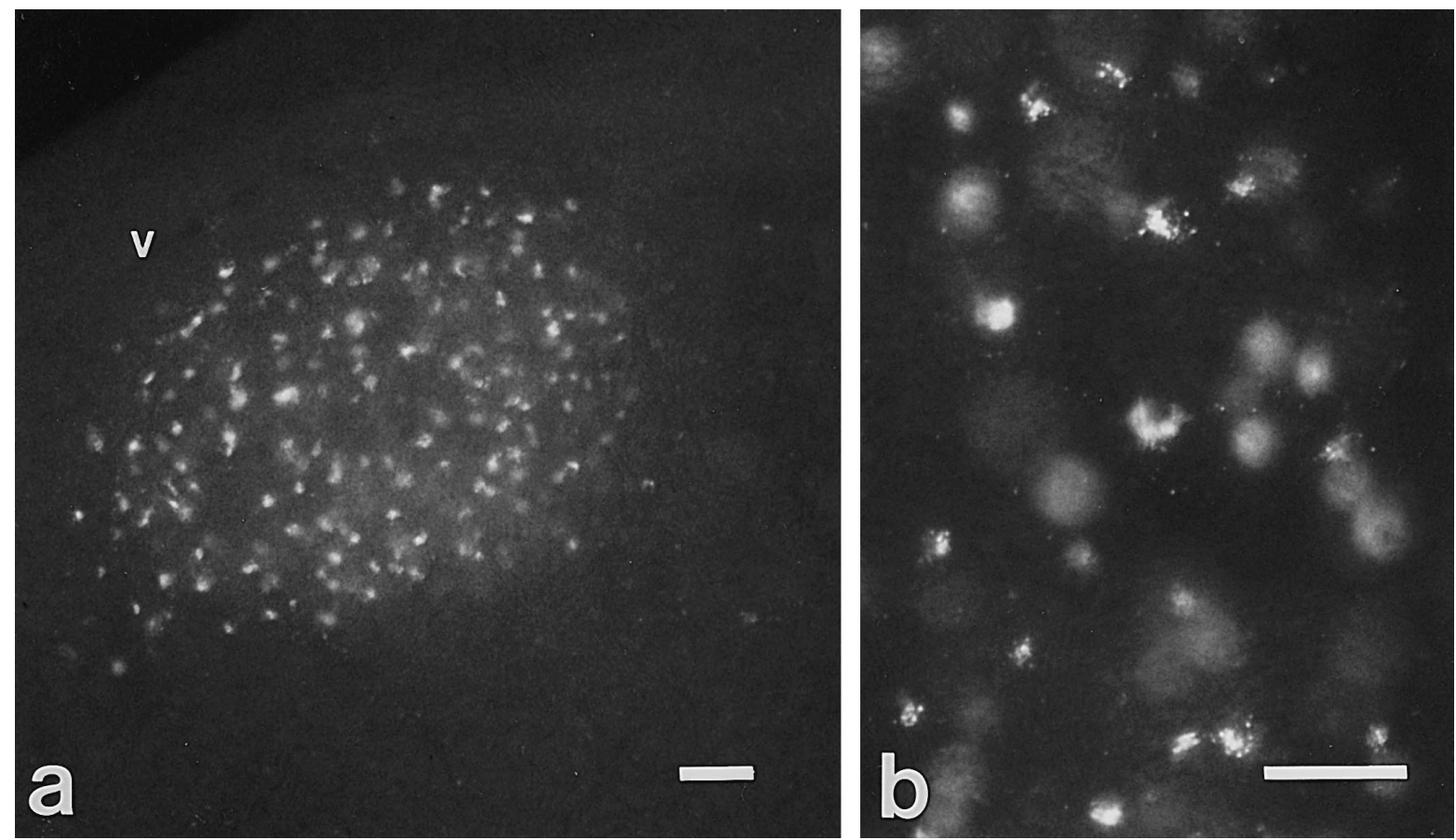

Fig. 2. Retrograde label over HVC. (a) Labeled Area X-projecting cells were confined to the borders of HVC and appeared to be evenly distributed. (b) Labeled cells viewed at the magnification used for LY injection, demonstrating that the fluorescent microspheres contained within a single cell provided a distinct target at which to direct the electrode. $\mathrm{v}=$ ventricle. Scale bar $=30 \mu \mathrm{m}$. 
weighted with filter paper, and the dish was filled with $\mathrm{PB}$ to just cover the section.

Retrogradely labeled Area X-projecting cells in HVC were located under a $40 \times$ long distance objective (Olympus) using a LY filter combination. Fluorescently labeled cells were readily identifiable and defined the border of HVC (Fig. 2a). A fine-tipped glass microelectrode (1.2 mm o.d., World Precision Instruments) pulled to a resistance of 80-140 M $\Omega$ resistance was backfilled with a 4\% solution of LY lithium salt (L-453, Molecular Probes) in distilled water. The electrode was fitted to a microelectrode holder (1.2 mm, World Precision Instruments) and advanced with a motorized micromanipulator (MS 314, World Precision Instruments). The electrode was first lowered into view and brought close to the surface of the tissue at the rostral extent of HVC. Labeled cells well below the tissue surface (Fig. 2b) were then selectively impaled by slowly advancing the electrode tip directly towards the vesiculated fluorescent microsphere target. Cells were filled iontophoretically with LY using a 1.5-2.5 nA negative current. Lower currents were used when a cell was first impaled to verify that the electrode tip had penetrated the desired cell. Infusion of pale yellow into the cell body with no leakage into the surrounding tissue confirmed proper impalement.

Individual cells filled rapidly and were generally considered to be completely filled within 10-15 min. Filling was assumed to be complete when visual inspection over a 2-3 min period did not reveal any further lengthening of dendrites, and when spines were visible along the length of the dendritic shaft. Occasionally, cells in well fixed tissue would fill slowly or not at all, remaining a dull yellow during initial filling attempts. The most common problem in these instances was that the tip had not completely penetrated the cell membrane. Advancing the tip further or re-poking the cell usually improved the quality of filling without damaging the cell. Filling generally proceeded in a rostral to caudal direction until three to five cells were filled throughout HVC. Stepwise progression across the nucleus prevented excessive bleaching of the fluorescent label and allowed for optimal distribution of filled cells to avoid the overlapping of dendrites from adjacent cells. Cells were filled in an average of four sections per bird, producing 5-12 well-filled, quantifiable Area X-projecting cells per canary.

\subsection{Lucifer Yellow immunocytochemistry}

Sections with LY filled cells were processed for immunocytochemistry within $24 \mathrm{~h}$ of filling. Sections were washed with fresh buffer before being incubated for 2-3 days in polyclonal anti-LY antibodies (A-5750, Molecular Probes) diluted 1:6000 in PB with 0.5\% Triton X-100. Two days at room temperature, or two days at $3{ }^{\circ} \mathrm{C}$ followed by one day at room temperature both resulted in very good immunostaining. Sections were washed in fresh buffer and incubated overnight $(8-16 \mathrm{~h})$ in secondary biotinylated goat anti-rabbit antibodies (Vectastain ABC Elite Kit, Vector) diluted 1:200 in PB. They were then washed again and incubated for $3 \mathrm{~h}$ in avidin-biotin solution (Vectastain ABC Elite Kit, Vector). Antibody staining was visualized in $\mathrm{PB}$ with $0.05 \%$ diaminobenzidine (DAB) (Sigma) treated with $0.015 \% \quad \mathrm{H}_{2} \mathrm{O}_{2}$ and enhanced with $0.025 \%$ cobalt chloride (Sigma) and $0.02 \%$ nickel ammonium sulfate (Fisher). Sections were washed in buffer and held in the heavy metal enhanced DAB solution for 15 min before being transferred to fresh $\mathrm{DAB}$ treated with peroxide. A period of 6 min for visualization produced dark, blue-black cells with low background staining; longer times resulted in a dark background that often obscured filled cells. Following final washes in buffer and distilled water, sections were mounted in the same orientation in which they were filled and allowed to air dry for at least 4 days. They were then counterstained with neutral red (Fisher), cleared twice in Histo-Clear (National Diagnostics) for 25 min each, and coverslipped with EM Glass (EM Sciences).

\subsection{Quantification}

Preliminary measurements of soma size and dendritic length were made from camera lucida drawings of three to five cells in each of seven birds (three short day, one long day untreated, and three long day T-treated). Somas and dendrites (two to three per cell) running parallel to the plane of section were drawn under oil at $945 \times$ magnification, and the spines along the entire length of drawn dendrites were counted. Analyses were restricted to dendrites parallel to the plane of sectioning to increase the accuracy of dendrites measured in the sagittal plane. Somal area and dendritic length were measured from the drawings with Image 1.61 software $(\mathrm{NIH})$, and the spine density was determined by dividing the total spine number by total dendritic length. Cell measurements were averaged by bird, and the values presented are the means and standard deviations of the averages from the seven birds without regard to treatment group.

\section{Results}

We found retrograde label in HVC only when the injection site encompassed part of Area X. In 14 birds in which the injection was just rostral or caudal to Area X, there were no labeled cells in HVC. The label appeared to be evenly distributed throughout HVC (Fig. 2), and an attempt was made to randomly fill cells in all regions. However, due to uncontrollable darkening and curling of the tissue along the dorsal ventricular border (see Fig. 3a), few quantifiable cells were obtained from this region. A cell was considered to be quantifiable if it was well-filled and was conclusively an Area X-projecting neuron. Well- 



Fig. 3. Female canary HVC containing several filled Area X-projecting neurons. (a) Arrow heads delineate the HVC boundary, and the shelf region is visible as the paler, fiber-rich zone ventral to HVC. Cells were large, spiny, and identified as thick dendrite cells. The left most cell had relatively short dendrites that extended into the shelf (b, arrows). Rostral is to the right. DA, dorsal archistriatal tract; LH, hyperstriatal lamina. Scale bar $=50 \mu \mathrm{m}$.

filled cells had dark dendrites of even density that typically terminated in spine-like extensions from the tip, and had filled spines with visible heads distributed along the entire dendritic length. Although great care was taken to impale only labeled cells, occasionally small unlabeled cells with somas apposed to labeled Area X-projecting cells were 

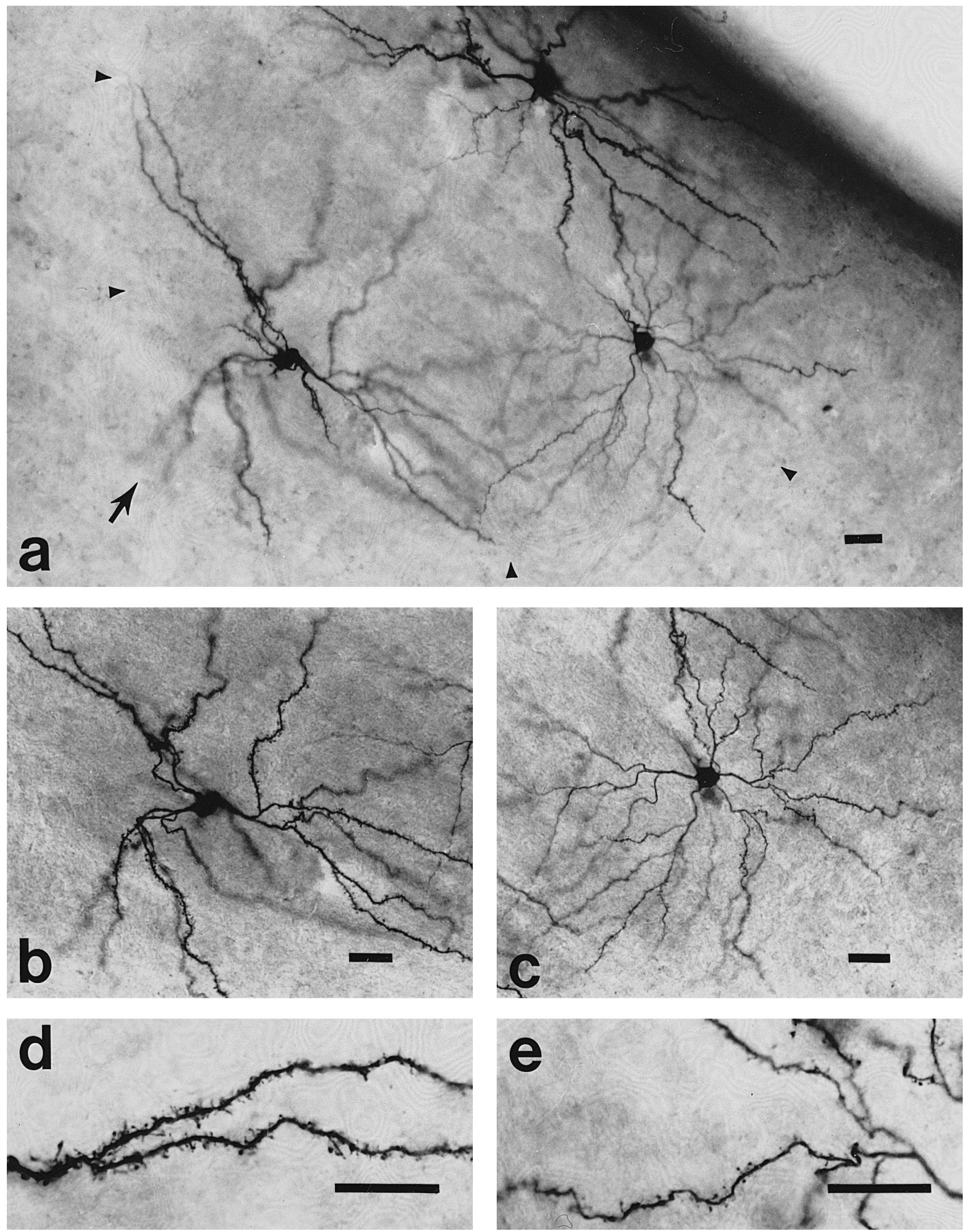

Fig. 4. The two possible subtypes of Area X-projecting cells. (a) HVC (arrowheads) with a typical thick dendrite (TD) cell (left) and a possible second type of Area X-projecting cell (right). Arrows indicate short dendrites that extend into the shelf region. The TD cell had a robust appearance (b) with moderately spiny dendrites (d). In contrast, the second cell class had a delicate appearance (c) with thinner, less spiny dendrites (e). Scale bar $=20 \mu \mathrm{m}$. 

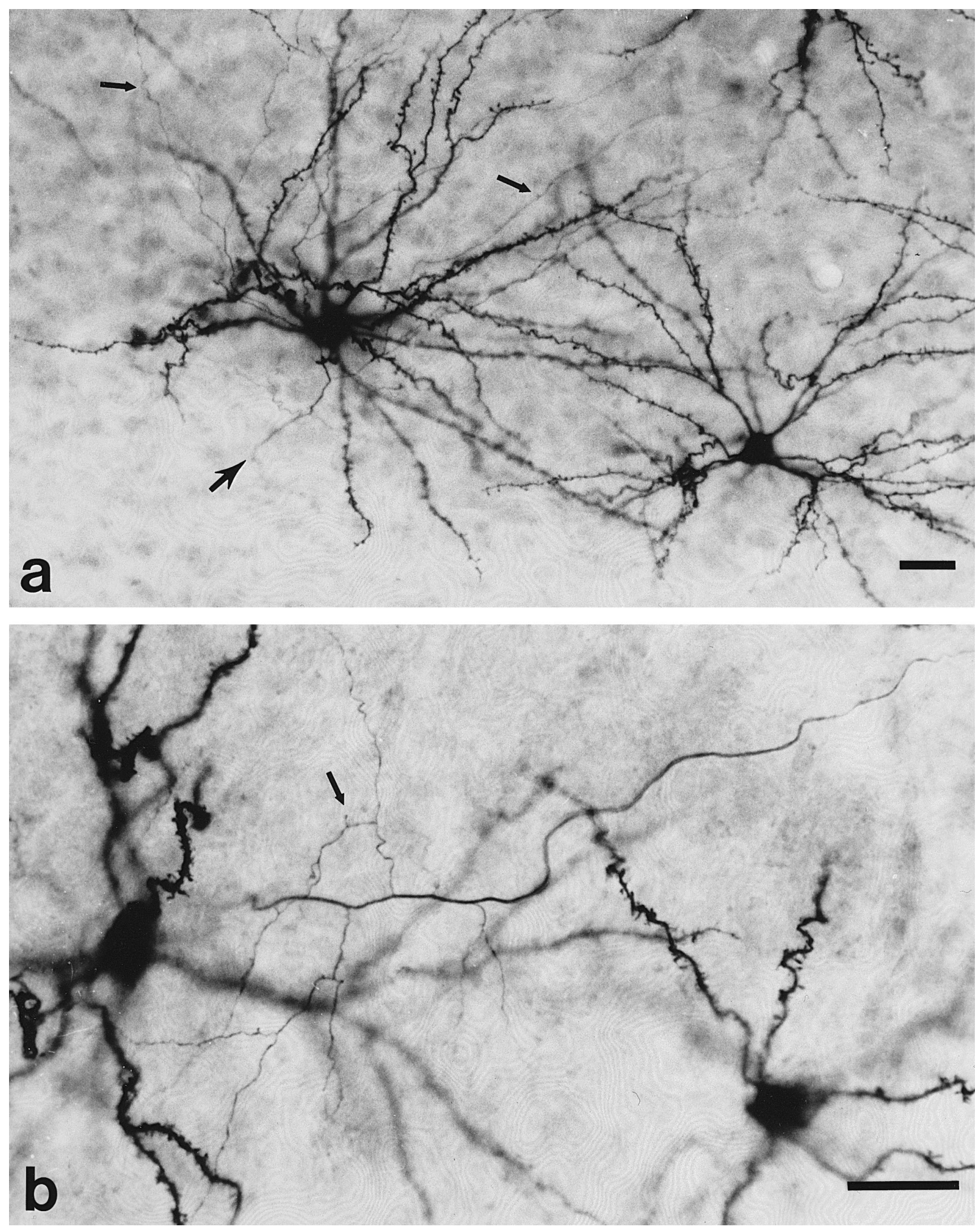

Fig. 5. Recurrent collaterals ramifying within HVC. (a) A well-filled axon (large arrow) from an Area X-projecting neuron along the ventral border of HVC with recurrent collaterals branching dorsally into the nucleus (small arrows). Note that the dendrites extending ventrally into the shelf region appear to be shorter than those extending into HVC. (b) Axon collaterals from an Area X-projecting neuron located within the body of HVC. Collaterals branch in all directions and travel within HVC. Spine-like terminals (small arrow) could be found close to the filled cell. Scale bar $=30 \mu \mathrm{m}$. 
impaled on approach. In such cases, filling was immediately terminated, and the incompletely filled cells could later be recognized by their short, fragile dendrites and lower density of staining. Axons often filled well beyond the border of HVC and traveled rostrally with the lamina hyperstriatica ( $\mathrm{LH})$, thus confirming the projection to Area $\mathrm{X}$. If there was any doubt of the cell class to which a filled cell belonged, it was not included in the analyses.

Filled Area X-projecting cells (seven birds, 24 cells, 49 measured dendrites) closely resembled Golgi-impregnated neurons of the TD class identified by Nixdorf et al. [18] in canaries. They had medium to large cell bodies $(136 \pm 35$ $\left.\mu \mathrm{m}^{2}\right)$, long radial dendrites $(154 \pm 29 \mu \mathrm{m})$, and a moderate spine density $(0.67 \pm 0.11$ per $\mu \mathrm{m})$ (Fig. 3$)$. The spine population on these Area X-projecting neurons was heterogeneous and included long, thin spines with no head, short-necked spines with small heads, and long-necked spines with large, round heads (see Fig. 4d). The spine density was visibly too low to be of the FD class (1.8 per $\mu \mathrm{m})$ and too high to be of the SD class $(0.4$ per $\mu \mathrm{m})$. The dendrites were longer than those of SD neurons which terminate within $140 \mu \mathrm{m}$ of the cell body, and the soma was larger than that of SD cells $\left(98 \mu \mathrm{m}^{2}\right)$. There were no readily apparent differences in cell morphology among the three treatment groups, but detection of subtle differences awaits further quantification.

Several cells, found in all three treatment groups, may represent a second class of Area X-projecting neurons. These cells had a more delicate appearance and a seemingly lower spine density than that observed on the majority of projection neurons (Fig. 4). They do not appear to be SD cells, as they have long dendrites and large somas similar to the filled TD-type cells. They were filled infrequently, suggesting that they were fewer in number than the TD type.

Cells along the ventral border of HVC had dendrites that project radially into the underlying shelf, defined as the fiber rich region along ventrolateral HVC [9] (Fig. 3a, Fig. 4a, Fig. 5a). Ventral dendrites in this cell class did not curve so as to either follow the ventral border of HVC or project back into the nucleus. Typically, dendrites extending into the shelf appeared to be shorter that those ramifying within HVC, as indicated by a reduced radial extension from the soma in the sagittal plane (Fig. 3b, Fig. 4b, Fig. 5a).

Well-filled axons of Area X-projecting cells had extensive recurrent collaterals that ramified within HVC. The collaterals branched near the soma and traveled towards the interior of HVC if the neuron was along the nuclear border (Fig. 5a), or traveled in all directions circumscribing the axon if the cell was located interiorly (Fig. 5b). Thus, the collaterals appeared to remain within the margins of HVC. In sections containing several cells with filled axons, the collaterals resembled a fine network of spineless fibers running throughout HVC. Though the collaterals did not fill completely to their ends, terminals resembling long, thin spines with bouton heads were found within the dendritic arborizations of the filled cell giving rise to the axon (Fig. 5b).

\section{Discussion}

We have successfully employed a cell filling technique to show definitively the morphology of Area X-projecting cells in the HVC of adult female canaries. We have resolved their identity as TD neurons, we have confirmed that they extend dendrites into the shelf region and have further characterized these dendrites as appearing shorter than those extending within the body of the nucleus, and we have demonstrated for the first time the existence of a network of recurrent collaterals ramifying within HVC.

The majority of Area X-projecting neurons in HVC, regardless of prior housing or hormonal treatment, match the morphological description of TD cells [18], thus confirming the supposition that TD cells project to Area X. Unlike previous studies which have provided compelling but inconclusive evidence of the morphological identity of HVC projection neurons, the cell filling technique has provided the first definitive characterization of a functional neuronal class. Cell filling has also allowed the identification of a potential second type of Area X-projecting cell. Fortune and Margoliash [9] also described a possible second class of Area X-projecting neurons, which had smaller somas and less spiny dendrites than TD neurons. However, their cells were not rigorously quantified and may actually have been incompletely filled neurons of the TD type, as suggested by the lack of spines shown along distal dendritic segments. Quantification of the filled cells in our study will reveal whether these cells represent a distinct class of Area X-projecting neurons or one extreme of the TD class. The three types of spiny cells described in HVC [18] have statistically distinct morphologies and, presumably, functional capabilities. Knowing the connectivity of each cell type is critical for future studies, especially those that combine physiological recording of HVC cells with in vivo filling. Our conclusive identification of Area X-projecting neurons, combined with future studies designed to identify RA-projecting neurons, will make it possible to assign recorded physiological characteristics to known classes of HVC cells.

We have confirmed earlier findings $[9,10]$ that $\mathrm{HVC}$ cells extend dendrites into the shelf region, and have demonstrated conclusively that Area X-projecting cells are among this population. The shelf receives auditory input from field $\mathrm{L}$ and from the caudomedial hyperstriatum ventrale $[9,11,28]$. The HVC cells with dendrites in this underlying region can make direct synaptic contact with these auditory afferents, thus providing a pathway for at least some of the auditory potentials recorded in $\mathrm{HVC}$ $[13,14,27]$. The shorter appearance of these dendrites sug- 
gests either a physical limitation, causing termination or diversion in the mediolateral direction, or functional subdivision of neurons along the ventral border of HVC. Accordingly, Area X-projecting cells with shorter dendrites into the shelf region may have physiological capabilities distinct from those of cells with dendrites wholly contained within the nucleus.

Cell filling has provided unequivocal evidence that Area X-projecting cells have recurrent collaterals that branch and terminate within HVC. Intrinsic HVC connections are extensive; minute localized tracer injections made in any HVC subregion results in label throughout the entire nucleus $[9,28]$. However, the nature of these intrinsic connections is not well-understood. It will be instructive to know which cells contribute to intra-HVC communication, which receive recurrent information, and whether such information is shared within or among cell classes. We now have evidence that Area X-projecting cells contribute to the communication within HVC through a network of recurrent collaterals. Specifically, Area X-projecting cells can receive direct auditory input through dendrites extending into the shelf region, and they can then provide processed efferent auditory information to other HVC cells, as well as to Area X. Katz and Gurney [10] first illustrated recurrent collaterals on presumed Area X-projecting cells that were filled with HRP in vivo. We have augmented their observation by describing the network of collaterals revealed over HVC when several projection neurons are simultaneously filled in a single section, and by demonstrating that at least a portion of the collaterals terminate within HVC. It may be possible to determine whether the recurrent collaterals synapse on adjacent Area X-projecting cells by combining this cell filling approach with subsequent electron microscopy.

One approach to deciphering the function of $\mathrm{HVC}$ in song learning and production is to examine how the physiology and anatomy of HVC change with the functional demands of the song system. An important behavioral demand is the T-dependent seasonal production of song [15,22,25]. Nissl studies have demonstrated that HVC volume and soma size increase in male songbirds on long days $[1,7,12,20,25]$, and testosterone treatment of female canaries masculinizes the brain by producing similar changes in HVC attributes [4,6,19]. While such findings demonstrate a major change in the activity of the nucleus, they cannot localize the mechanism of change. The specific components of HVC must be examined in order to determine which are responsible for the observed global changes and to describe the nature of any morphological modifications. Cell filling provides a powerful tool for identifying the song related changes in HVC neuronal morphology which reflect the cellular mechanisms coordinating the activity of the nucleus. We are confident that the cell filling technique will prove to be an invaluable method in future song system research.

\section{Acknowledgements}

We thank Elizabeth Walhausser-Franke for her introduction to the cell filling technique, Barbara Finlay for the use of her equipment, Randy Snow for his invaluable advice during times of great frustration, and Sarah Newman, David Airey and Tom Smulders for their comments on the manuscript. This research was supported in part by a President's Council of Cornell Women Grant to S.B. and a grant from NIH (RO1 MH56093) to T.J.D.

\section{References}

[1] O. Arai, I. Taniguchi, N. Saito, Correlation between the size of song control nuclei and plumage color change in orange bishop birds, Neurosci. Lett. 948 (1989) 144-148.

[2] S. Benton, D.A. Nelson, P. Marler, T.J. DeVoogd, Anterior forebrain pathway is needed for stable song expression in adult male white-crowned sparrows (Zonotrichia leucophrys), Behav. Brain Res. (1998), in press.

[3] S.W. Bottjer, E.A. Miesner, A.P. Arnold, Forebrain lesions disrupt development but not maintenance of song in passerine birds, Science 224 (1984) 901-903.

[4] S.W. Bottjer, J.N. Schoonmaker, A.P. Arnold, Auditory and hormonal stimulation interact to produce neural growth in adult canaries, J. Neurobiol. 17 (1986) 605-612.

[5] S.W. Bottjer, K.A. Halsema, S.A. Brown, E.A. Miesner, Axonal connections of a forebrain nucleus involved with vocal learning in zebra finches, J. Comp. Neurol. 279 (1989) 312-326.

[6] E.A. Brenowitz, A.P. Arnold, The effects of systemic androgen treatment on androgen accumulation in song control regions of the adult female canary brain, J. Neurobiol. 21 (1990) 837-843.

[7] E.A. Brenowitz, B. Nalls, J.C. Wingfield, D.E. Kroodsma, Seasonal changes in avian song nuclei without seasonal changes in song repertoire, J. Neurosci. 11 (1991) 1367-1374.

[8] E.S. Fortune, D. Margoliash, Cytoarchitectonic organization and morphology of cells of the field L complex in male zebra finches (Taenopygia guttata), J. Comp. Neurol. 325 (1992) 388-404.

[9] E.S. Fortune, D. Margoliash, Parallel pathways and convergence onto HVC and adjacent neostriatum of adult zebra finches (Taeniopygia guttata), J. Comp. Neurol. 360 (1995) 413-441.

[10] L.C. Katz, M.E. Gurney, Auditory responses in the zebra finch's motor system for song, Brain Res. 211 (1981) 192-197.

[11] D.B. Kelly, F. Nottebohm, Projections of a telencephalic auditory nucleus-field L in the canary, J. Comp. Neurol. 193 (1979) 455-470.

[12] J.R. Kirn, R.P. Clower, D.E. Kroodsma, T.J. DeVoogd, Song-related brain regions in the red-winged blackbird are affected by sex and season but not by repertoire size, J. Neurobiol. 20 (1989) 139-163.

[13] D. Margoliash, Preference for autogenous song by auditory neurons in a song system nucleus of the white-crowned sparrow, J. Neurosci. 6 (1986) 1643-1661.

[14] D. Margoliash, E.S. Fortune, Temporal and harmonic combinationsensitive neurons in the zebra finch's HVC, J. Neurosci. 12 (1992) 4309-4326.

[15] P. Marler, S.S. Peters, G.F. Ball, A.M. Dufty, J.C. Wingfield, The role of sex steroids in the acquisition and production of birdsong, Nature 336 (1988) 770-772.

[16] J.S. McCasland, M. Konishi, Interaction between auditory and motor activities in an avian song control nucleus, Proc. Natl. Acad. Sci. USA 78 (1981) 7815-7819.

[17] G.E. Meredith, P. Ypma, D.S. Zahm, Effects of dopamine depletion 
on the morphology of medium spiny neurons in the shell and core of the rat nucleus accumbens, J. Neurosci. 15 (1995) 3808-3820.

[18] B.E. Nixdorf, S.S. Davis, T.J. DeVoogd, Morphology of golgi-impregnated neurons in hyperstriatum ventralis, pars caudalis in adult male and female canaries, J. Comp. Neurol. 284 (1989) 337-349.

[19] F. Nottebohm, Testosterone triggers growth of brain vocal control nuclei in adult female canaries, Brain Res. 199 (1980) 429-436.

[20] F. Nottebohm, A brain for all seasons: cyclical anatomical changes in song control nuclei of the canary brain, Science 214 (1981) $1368-1370$.

[21] F. Nottebohm, D.B. Kelly, J.A. Paton, Connections of vocal control nuclei in the canary telencephalon, J. Comp. Neurol. 207 (1982) 344-357.

[22] F. Nottebohm, M.E. Nottebohm, L.A. Crane, J.C. Wingfield, Seasonal changes in gonadal hormone levels of adult male canaries and their relation to song, Behav. Neural Biol. 47 (1987) 197-211.

[23] S. Okuhata, F. Nottebohm, Single units in nucleus UVA respond to sound and respiration and are part of a motor loop involved in song production, in: Proceedings of the Third International Congress of Neuroethology, 1992, p. 60.

[24] M. Rocha, M. Sur, Rapid acquisition of dendritic spines by visual thalamic neurons after blockade of $N$-methyl-D-aspartate receptors, Proc. Natl. Acad. Sci. USA 92 (1995) 8026-8030.

[25] G.T. Smith, E.A. Brenowitz, J.C. Wingfield, L.F. Baptista, Seasonal changes in song nuclei and song behavior in Gambel's white-crowned sparrow, J. Neurobiol. 28 (1995) 114-125.
[26] T.M. Stokes, C.M. Leonard, F. Nottebohm, The telencephalon, diencephalon, and mesencephalon of the canary, Serinus canaria, in stereotaxic coordinates, J. Comp. Neurol. 156 (1974) 317-374.

[27] M.L. Sutter, D. Margoliash, Global synchronous response to autogenous song in zebra finch HVc, J. Neurophysiol. 72 (1994) 21052123.

[28] G.E. Vates, B.M. Broome, C.V. Mello, F. Nottebohm, Auditory pathways of caudal telencephalon and their relation to the song system of adult male zebra finches (Taenopygia guttata), J. Comp. Neurol. 366 (1996) 613-642.

[29] E.T. Vu, M.E. Mazurek, Y. Kuo, Identification of a forebrain motor programming network for the learned song of zebra finches, J. Neurosci. 14 (1994) 6924-6934.

[30] J.M. Wild, Visual and somatosensory inputs to the avian song system via nucleus uvaeformis (Uva) and a comparison with the projections of a similar thalamic nucleus in a non-songbird, Columba livia, J. Comp. Neurol. 349 (1994) 512-535.

[31] H. Williams, Multiple representations and auditory-motor interactions in the avian song system, Ann. New York Acad. Sci. 563 (1989) 148-164.

[32] H. Williams, D.S. Vicario, Temporal patterning of song production: participation of nucleus uvaeformis of the thalamus, J. Neurobiol. 24 (1993) 903-912.

[33] A.C. Yu, D. Margoliash, Temporal hierarchical control of singing in birds, Science 273 (1996) 1971-1975. 